\title{
INTERPRETATION OF GROUNDWATER CHEMISTRY DATA USING MULTIVARIATE STATISTICAL TECHNIQUES
}

\author{
REHMAN F. ${ }^{1,2}$ \\ CHEEMA T. ${ }^{3}$ \\ ABUELNAGA H.S.O. ${ }^{1}$ \\ HARBI H.M. ${ }^{1}$ \\ ATEF A.H. ${ }^{1}$ \\ LISA M. ${ }^{4}$
}

\author{
${ }^{1}$ Department of Geophysics, Faculty of Earth Sciences \\ King Abdulaziz University, KSA \\ ${ }^{2}$ Department of Earth Sciences \\ COMSATS Institute of Information Technology, Abbottabad, Pakistan \\ ${ }^{3}$ Department of Hydrogeology, Faculty of Earth Sciences \\ King Abdulaziz University, KSA \\ ${ }^{4}$ Department of Earth Sciences, Quaid-i-Azam University \\ Islamabad, Pakistan
}

Received: $14 / 02 / 2016$

Accepted: $11 / 03 / 2016$

Available online: $25 / 07 / 2016$

\begin{abstract}
Hydrogeologists in general and hydrogeochemists in particular are commonly asked to collect and interpret groundwater chemistry data for determining the groundwater quality at a particular site. More often, this involves graphical representation of data and a comparison with the drinking water quality standards. However, public laws and regulations require rigorous and a comprehensive quantitative approach, including statistical analysis to interpret the groundwater chemistry data. The analysis might be helpful in identifying the contaminated sites.
\end{abstract}

A total of 19 groundwater samples were collected from Wadi Bani Malik located $40 \mathrm{~km}$ to the east of Jeddah, Saudi Arabia. The area once known to be a dumping ground for untreated waste has now been partially remediated. To establish that the higher concentration of salts found in the Wadi is due to the sewage dumping, the data were compared with an adjacent Wadi Madsus that was not known to have any history of dumping. A distribution-free method of multivariate data analysis was employed to compare the variation in species abundance and composition among sampling sites.

Principal Coordinate Analysis indicates that some of the wells in both the wadis have same compositional trend and also some samples overlap within the same area. Analysis of similarity (ANOSIM) using $R$ package vegan software indicates a strong correlation $(R=0.82)$ between Wadi Bani Malik and Wadi Madsus. The $P$ factor calculated while performing the analysis suggests that sewage dumping significantly contaminated

$(P=0.001)$ the groundwater quality of the Bani Malik area.

Keywords: Multivariate, Analysis, Concentration, Madsus, Bani Malik, Statistical, Wadi.

\section{Introduction}

Groundwater is considered as a substantial share of total natural water resources in arid and semi-arid regions. The quality of the groundwater variation is a function of chemical and physical patterns in an area determined by geological and anthropogenic activities. The effectiveness of water for a precise function is defined by the water quality (Srinivasamoorthy et al., 2014; Subyani and Al Ahmadi, 2010). The 
properties and ionic concentrations in groundwater depend on the hydrogeochemical processes. These properties are controlled by natural processes, mineral weathering, precipitation and evaporation crystallization. Understanding groundwater quality and hydrochemistry are significant because they are the principal ingredients that influence water chemistry, mechanisms controlling chemistry, classification of water type, water rock interaction, geochemical evolution, and water relevance for different uses (Jabal et al., 2015). The information of hydrochemistry is vital to find the source of chemical composition of groundwater. The significance of hydrochemistry of groundwater has led to a number of detailed written reports on groundwater quality decline and geochemical evolution of groundwater in many regions of the world (Srinivasamoorthy et al., 2014; Zhang et al., 2011). This success of hydrochemistry dictates the hydrogeologists in general and hydrogeochemists in particular to collect groundwater interpret groundwater chemistry data for determining the groundwater quality at a particular site. More often, this involves graphical representation of data and a comparison with the drinking water quality standards. However, public laws and regulations require rigorous and a comprehensive quantitative approach that might be helpful in identifying the contaminated sites.

In late years, with increasing number of chemical and physical variables of groundwater, a broad scope of statistical methods is now utilized for proper analysis and interpretation of information. The generally used techniques for groundwater contamination studies are statistical techniques, especially multivariate statistics. By applying multivariate statistical analysis of a vast data set, the interpretation can be simplified by means of rotational procedures, finding similarities among variables and hence contributing to meaningful insight. Multivariate statistical analysis includes a number of statistical methods or a set of algorithms that may be used in various areas of empirical investigation. The purpose of these techniques for evaluating the water quality is to identify the most severe vicinities forbidden from drinking and irrigation uses. Instead, it can be achieved to distinguish the studied localities into groups; each has its specific composition and geographic setting; taking into consideration the depiction of the various ingredients in water and water usage (Dragon, 2008; Lin et al., 2012; Morsi et al., 2015; Subyani and Al Ahmadi, 2010; Sun and Gui, 2015). Multivariate statistical analysis includes a number of techniques, e.g. Principal Coordinates Analysis, Principal Component Analysis, Analysis of Similarity, Analysis of Variance, Cluster Analysis, Hierarchical cluster, Shannon index, Factor analysis, etc. Some of the those methods have given a better apprehension of the physical and chemical attributes of the groundwater system in place as well as in time (Clarke and Warwick, 2001; Dehghanzadeh et al., 2014; Forrest et al., 2013; Subyani and Al Ahmadi, 2010; Suresh et al., 2009; Zuur et al., 2007).

From all the multivariate statistical analyses as mentioned above, Analysis of Similarity and Principal Coordinate Analysis techniques are rarely used in groundwater contamination studies. But when it come to find out the differences between groups of samples, similarities and dissimilarities and variance in data sets, these methods have successfully been used in biological and marine sciences by several investigators (Clarke and Warwick, 2001; Forrest et al., 2013; Morsi et al., 2015; Ramette, 2007). Because of their successes in determining the similarities and dissimilarities between the two data sets in other disciplines, the Principal Coordinate Analysis (PCOA) and the Analysis of Similarity (ANOSIM) remain the primary focus for finding the presence (or absence) of groundwater contamination in our study area.

\section{Materials and Methods}

\subsection{Study Area}

The subject field is situated around $40 \mathrm{~km}$ east side of Jeddah, one of the major urban centers in Saudi Arabia. It delivers more than three hundred thousand residents and population is increasing $2.35 \%$ per year. The water depletion is approximately 200 liters per capita per day. On average, $80 \%$ of drinkable water used for urban purposes proceeds to the environment as waste water. Approximately $70 \%$ of Jeddah area are not related to sewerage pipelines; waste water collected in underground cesspools and then by truck tankers wastewater is transported to the Al Misk lake for the past more than 10 years. It was estimated that more than 800 tankers dumped 40,000 cubic meters of waste water into the lake 
every day and the amount has expanded drastically (Elfeki et al., 2010; Ewea, 2010; Rehman et al., 2016a; Rehman and Cheema, 2016). According to Moore and Al-Rehaili (1989) the rock units of the study area are subdivided into following units; Madrakah formation, unassigned metagabbro and gabbro, Dighbij complex, Hafnah complex, syenogranite and finally Quaternary deposits and mafic dykes. Basement rocks are formed of Late Proterozoic basaltic to rhyolitic volcanics and volcanistics. Cenozoic sedimentary rocks are recorded underlying a cover of flat lying lavas and quaternary deposits (Rehman et al., 2016b; Sharaf, 2012).

\subsection{Groundwater Sampling and Analysis}

A groundwater well survey was directed in order to gather the field hydrogeological parameters and to identify the groundwater wells for geochemical analysis. Total 19 water samples gathered up for major ion analysis from Wadi Bani Malik area. The geochemical analysis was done by following standard techniques. The major cations include calcium, magnesium, sodium, potassium $\left(\mathrm{Ca}^{++}, \mathrm{Mg}^{++}, \mathrm{Na}^{+}, \mathrm{K}^{+}\right)$, whereas anions comprise of sulfate, carbonate, bicarbonate, chloride $\left(\mathrm{SO}_{4}^{--}, \mathrm{CO}_{3}^{--}, \mathrm{HCO}_{3}^{-}\right.$and $\left.\mathrm{Cl}^{-}\right)$along with the total dissolved solids, electrical conductivity and total hardness.

Hydrochemical analysis results indicate a very high concentration of major cations, anions, total dissolved solids and total hardness. As the Wadi Bani Malik has a history of dumping untreated sewage waste and higher concentration of ions in this location might be as a result of this dumping. Groundwater analysis of Wadi Bani Malik was compared with a pristine (non-contaminated) Wadi Madsus located in the same hydrogeologic setting in the vicinity of Jeddeah. Groundwater data of Wadi Bani Madsus were collected from literature (Sharaf, 2012)

\subsection{Statistical Analysis}

Statistical analysis, including the basic statistics, ANOSIM (Analysis of Similarity) and PCoA (Principal Coordinate Analysis) analyses were performed by using $R$ package vegan software. $R$ signifies statistical computation and graphics. The software also has the abilitity to run a program stored in script files. Vegan is potentially used for different purposes including diversity analysis, statistical analysis and element distribution. The analysis was performed by making use of 32 samples. Samples 1 to 19 are related to Wadi Bani Malik while the remaining 20 to 32 samples represent Madsus area.

\subsubsection{PCOA (Principal Coordinate Analysis)}

Principal coordinate analysis is also referred as classical scaling, metric multidimensional scaling and correspondence analysis. The objectives of Principal Coordinate Analysis are similar to the Principal Component Analysis in that it applies a linear mapping of the distance or deviations between objects to explicate most of the variance in the original data set (Ibekwe et al., 2012; Ramette, 2007; Zuur et al., 2007). Principal Coordinate Analysis is used to identify and to envision the similarities and dissimilarities of data (Morsi et al., 2015).

\subsubsection{ANOSIM (Analysis of Similarity)}

ANOSIM is nonparametric and multivariate equivalent to ANOVA (Analysis of Variance) and test the differences among groups. ANOSIM gives the significance level ( $P$ value) and the strength of the factors on the samples ( $R$ value). The strength of the factor ( $R$ value) is supposed to vary between 0 and 1 . Negative values of $P$ can also be obtained, but they are always close to 0 . The value of $R$ can never lie outside the range of -1 and 1 . The strength of the factor close to 1 indicates a high separation between levels of the factor (value of $\mathrm{R}$ close to 1 proposes dissimilarity between groups), while close to 0 indicate no separation between the levels of the factor (if the $R$ value is low e.g. 0.2 this means factor have small effect on variables). The value of $R$ only equal to 1 when all replicates within the sites are more similar to each other than any replicates from different site (Clarke and Warwick, 2001; Forrest et al., 2013; Griebler et al., 2010; Hahn and Fuchs, 2009; Schmidt et al., 2007). 


\section{Results and Discussion}

\subsection{Groundwater Chemistry Data}

\subsubsection{Wadi Bani Malik}

Major cations present in the ground water are calcium, magnesium, sodium and potassium, whereas the major anions are sulfate, carbonate, bicarbonate and chloride. Summary statistics for concentration of physicochemical parameters in Wadi Bani Malik area is shown in Table 1. Also shown in the Table is the drinking water standards of the Kingdom of Saudi Arabia (KSA). In the study area, the concentration of calcium varies from 160.32 to $3767.5 \mathrm{mg} \mathrm{l}^{-1}$ with a mean value of $1556.77 \mathrm{mg} \mathrm{l}^{-1}$. The maximum allowed concentration of calcium is about $200 \mathrm{mg} \mathrm{l}^{-1}$. According to allowable concentration, only one sample was found to be within the desirable limit. The concentration of magnesium ranges from 0.4864 to $1605.12 \mathrm{mg} \mathrm{l}^{-1}$ with average value of $588.92 \mathrm{mg} \mathrm{l}^{-1}$. Only one sample which is about $5.2 \%$ of total samples placed in the allowed concentration. Sodium concentration in the study area ranges from 3000 to $17900 \mathrm{mg} \mathrm{l}^{-1}$ with an average value of $7349.05 \mathrm{mg} \mathrm{l}^{-1}$. Compared with KSA and WHO standards, all the samples fall in the undesirable limit which is about $200 \mathrm{mg} \mathrm{l}^{-1}$. The potassium concentration varies from 6.1 to $320 \mathrm{mg} \mathrm{l}^{-1}$ with a mean value of $38.79 \mathrm{mg} \mathrm{l}^{-1}$. About six samples that are about $31.5 \%$ of total samples fall in the safe limit prescribed by WHO (2011) which is $20 \mathrm{mg} \mathrm{l}^{-1}$.

Sulfate concentration ranges 724.3 to $8645.5 \mathrm{mg} \mathrm{l}^{-1}$ with an average value of $3665.24 \mathrm{mg} \mathrm{l}^{-1}$. The maximum allowed concentration of Sulfate is $400 \mathrm{mg} \mathrm{l}^{-1}$ and none of a water sample in the study area falls in the safe limits. In the study area, carbonate ranges from 10 to $1128 \mathrm{mg} \mathrm{l}^{-1}$ with a mean value of $218.98 \mathrm{mg} \mathrm{I}^{-}$ ${ }^{1}$, whereas a value of bicarbonate ranges from 24.4 to $1040.66 \mathrm{mg} \mathrm{l}^{-1}$ with an average value of $283.82 \mathrm{mg}$ $\mathrm{I}^{-1}$. All the water samples in the study area exceeded the allowed chloride limit which is about $600 \mathrm{mg} \mathrm{l}^{-1}$, whereas in the study area, chlorides limit ranges from 3195 to $29820 \mathrm{mg} \mathrm{l}^{-1}$ with a mean of $12303.55 \mathrm{mg}$ $\mathrm{I}^{-1}$. Total dissolved solids range from 10008 to $26130.21 \mathrm{mg} \mathrm{l}^{-1}$ with an average value of $57240 \mathrm{mg} \mathrm{l}^{-1}$. All the water samples have very high TDS concentration as compared to the allowed concentration in Kingdom of Saudi Arabia and WHO (2011) those are 1500 and $1000 \mathrm{mg} \mathrm{l}^{-1}$ respectively. Electrical conductivity and ions concentration present in the water are directly related and in the study area its value range from 12.49 to $92.5 \mathrm{mS} \mathrm{cm}^{-1}$ with a mean of $36.29 \mathrm{mS} \mathrm{cm}^{-1}$. Electrical conductivity values indicate the amount of TDS, which in turn specifies the inorganic pollution load of water and assists as an index to symbolize the total absorption of soluble salts in water. All the water samples in the study area exceeded the suggested limit by WHO (2011) which is about $1.5 \mathrm{mS} \mathrm{cm}^{-1}$. Generally, total hardness increases with the increase of calcium and magnesium ions. In the study area total hardness range from 1404.79 to $13008.38 \mathrm{mg} \mathrm{l}^{-1}$ with an average of $6306.47 \mathrm{mg} \mathrm{l}^{-1}$. Whereas the desirable limit for total hardness is about 300-500 mg l-1 according to KSA standards and $500 \mathrm{mg} \mathrm{l}^{-1}$ from WHO (2011) standards.

Table 1. Summary statistics for concentration of physicochemical parameters in Wadi Bani Malik area.

\begin{tabular}{|c|c|c|c|c|c|c|}
\hline Parameters & Units & Min & Max & Ave & St. Dev & KSA \\
\hline $\mathbf{C a}^{++}$ & $\mathrm{mg} \mathrm{l}^{-1}$ & 160 & 3767 & 1557 & 848 & 200 \\
\hline $\mathbf{M g}^{++}$ & $\mathrm{mg} \mathrm{l}^{-1}$ & 0.5 & 1605 & 589 & 331 & $30-150$ \\
\hline $\mathbf{N a}^{+}$ & $\mathrm{mg} \mathrm{l}^{-1}$ & 3000 & 17900 & 7349 & 3536 & 200 \\
\hline $\mathbf{K}^{+}$ & $\mathrm{mg} \mathrm{l}^{-1}$ & 6 & 320 & 39 & 69 & - \\
\hline $\mathbf{S O}_{4}^{--}$ & $\mathrm{mg} \mathrm{l}^{-1}$ & 724 & 8645 & 3665 & 1794 & 400 \\
\hline $\mathbf{C O}_{3}^{--}$ & $\mathrm{mg} \mathrm{l}^{-1}$ & 10 & 1128 & 219 & 256 & - \\
\hline $\mathbf{H C O}_{3}^{-}$ & $\mathrm{mg} \mathrm{l}^{-1}$ & 24 & 1041 & 284 & 259 & - \\
\hline $\mathbf{C l}^{-}$ & $\mathrm{mg} \mathrm{l}^{-1}$ & 3195 & 29820 & 12303 & 6616 & 600 \\
\hline TDS & $\mathrm{mg} \mathrm{l}^{-1}$ & 10008 & 57240 & 26130 & 10923 & 1500 \\
\hline E.C & $\mathrm{mS} \mathrm{cm}^{-1} \mathbf{)}$ & 12 & 92 & 36 & 19 & - \\
\hline Total Hardness & $\mathrm{mg} \mathrm{l}^{-1}$ & 1405 & 13008 & 6306 & 2729 & $300-500$ \\
\hline
\end{tabular}

Figure 1 shows the percentage of major ions in all 19 groundwater samples in the study area. From examination, it is clear that the chloride and sodium are most abundant anions and cations respectively 
in the study area. Chloride is most abundant ion in all the wells, which ranges from 31 to $59 \%$ of the wells. Sodium is the second most abundant ion that ranges from 21 to $32 \%$ of the wells. Third most abundant ion is Sulfate that ranges from 3 to $31 \%$ in the study area. The less abundant ions in the study area are calcium, magnesium, bicarbonate and carbonate whereas the least one is potassium.

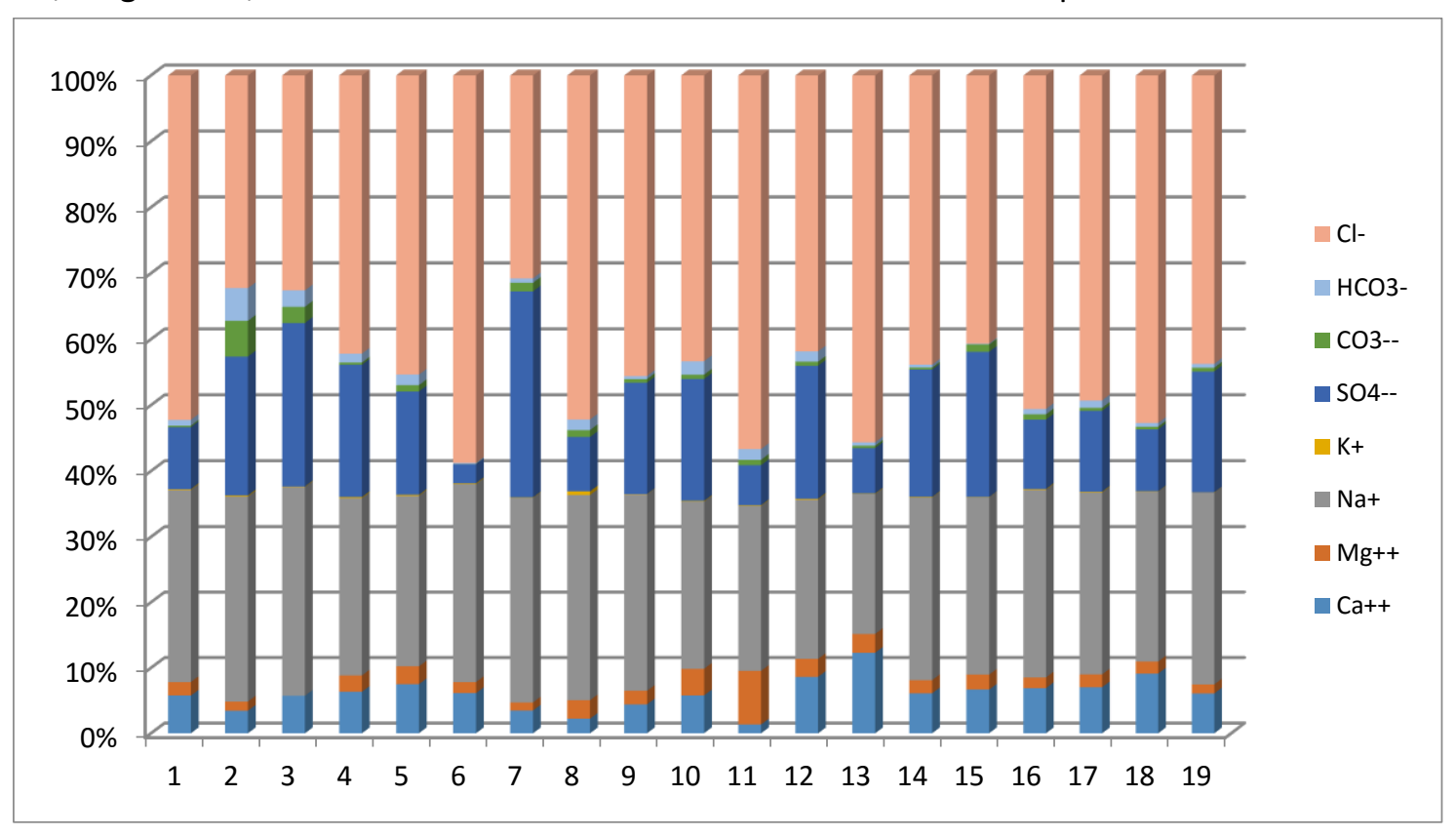

Figure 1. Percentage of major ions in all the water wells of Wadi Bani Malik Area

\subsubsection{Wadi Madsus}

Summary statistics of physicochemical parameters obtained after analyzing 13 groundwater samples of Wadi Madsus (Table 2) show that the most abundant ions are chloride and sulfate whereas sodium is the third most abundant ion. Figure 2 shows the percentage of major ions in all 13 groundwater samples from Wadi Madsus. The concentration of Chloride is maximum followed by sulfate and sodium.

Table 2. Summary statistics for concentration of physicochemical parameters in the Wadi Madsus area (Sharaf, 2012)

\begin{tabular}{|c|c|c|c|c|c|}
\hline Parameters & Units & Min & Max & Ave & St. Dev \\
\hline $\mathbf{C a}^{++}$ & $\mathrm{mg} \mathrm{l}^{-1}$ & 72 & 1082 & 316 & 290 \\
\hline $\mathbf{M g}^{++}$ & $\mathrm{mg} \mathrm{l}^{-1}$ & 45 & 608 & 210 & 179 \\
\hline $\mathbf{N a}^{+}$ & $\mathrm{mg} \mathrm{l}^{-1}$ & 121 & 1685 & 555 & 487 \\
\hline $\mathbf{K}^{+}$ & $\mathrm{mg} \mathrm{l}^{-1}$ & 0.2 & 6 & 3 & 2 \\
\hline $\mathbf{S O}^{--}$ & $\mathrm{mg} \mathrm{l}^{-1}$ & 224 & 2404 & 982 & 870 \\
\hline $\mathbf{C O}^{--}$ & $\mathrm{mg} \mathrm{l}^{-1}$ & 0 & 48 & 19 & 13 \\
\hline $\mathbf{H C O}_{3}^{-}$ & $\mathrm{mg} \mathrm{l}^{-1}$ & 154 & 227 & 197 & 20 \\
\hline $\mathbf{C l}^{-}$ & $\mathrm{mg} \mathrm{l}^{-1}$ & 276 & 4417 & 1211 & 1187 \\
\hline TDS & $\mathrm{mg} \mathrm{l}^{-1}$ & 1112 & 13556 & 4203 & 3759 \\
\hline E.C & $\mathrm{mS} \mathrm{cm}^{-1}$ & 1 & 17 & 5 & 5 \\
\hline Total Hardness & $\mathrm{mg} \mathrm{l}^{-1}$ & 420 & 5198 & 1653 & 1438 \\
\hline
\end{tabular}

A comparison of major ions in Wadi Bani Malik and Wadi Madsus is shown in Figure 3. The concentration of sodium, potassium and chloride is much higher (around 90\%) and lower in bicarbonate (55\%) when compared with Wadi Madsus. The higher concentration in wadi Bani Malik as compared to Wadi Madsus indicates the presence of most common salts as a result of dumping of untreated waste in Wadi Bani Malik. Overall average concentration of major ions in wadi Bani Malik is around $74 \%$ more than the wadi Madsus (Figure 3). 


\subsection{PCoA (Principal Coordinate Analysis)}

The correspondence analysis of groundwater samples in Wadi Bani Malik and Wadi Madsus is shown in the form of plots in Figures 4 and 5. As the groundwater samples could not be plotted in Figure 5, Figure 4 was generated that showed all the groundwater samples of both the wadis. Every single well is represented by a point and the distance between the points represents how the wells composition is different from one another. Figure 4 shows few wells overlapping others and are plotted as clusters. This indicates that the overlapping wells have similar chemical composition within two wadis (e.g., well no 9,14,19 etc in Bani Malik and 26,27 in Madsus). Few wells in Wadi Madsus (e.g., 25-27, 29, 32) deviate from the other wells due to high variation in composition within same Wadi.

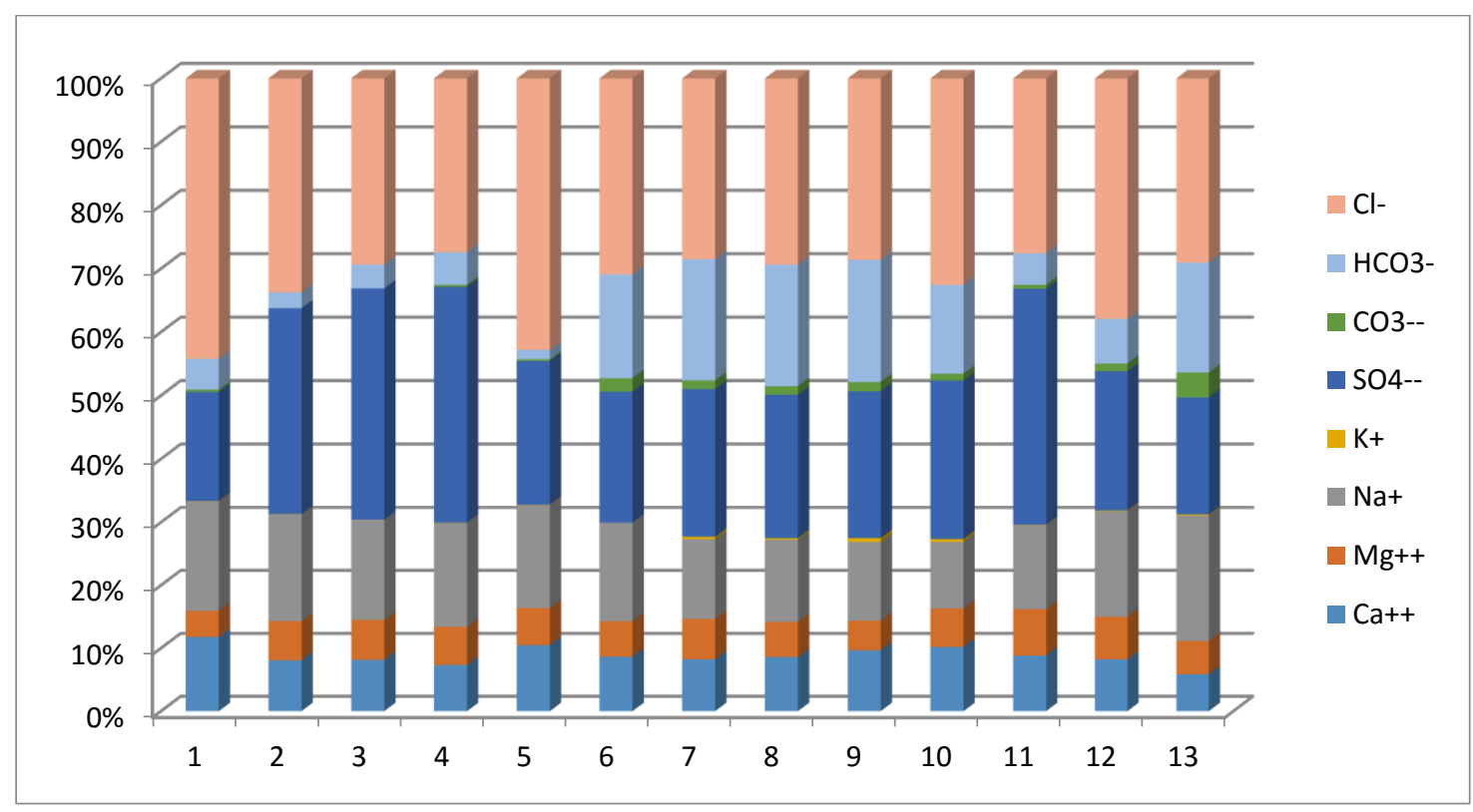

Figure 2. Percentage of major ions in all the water wells in Wadi Madsus Area

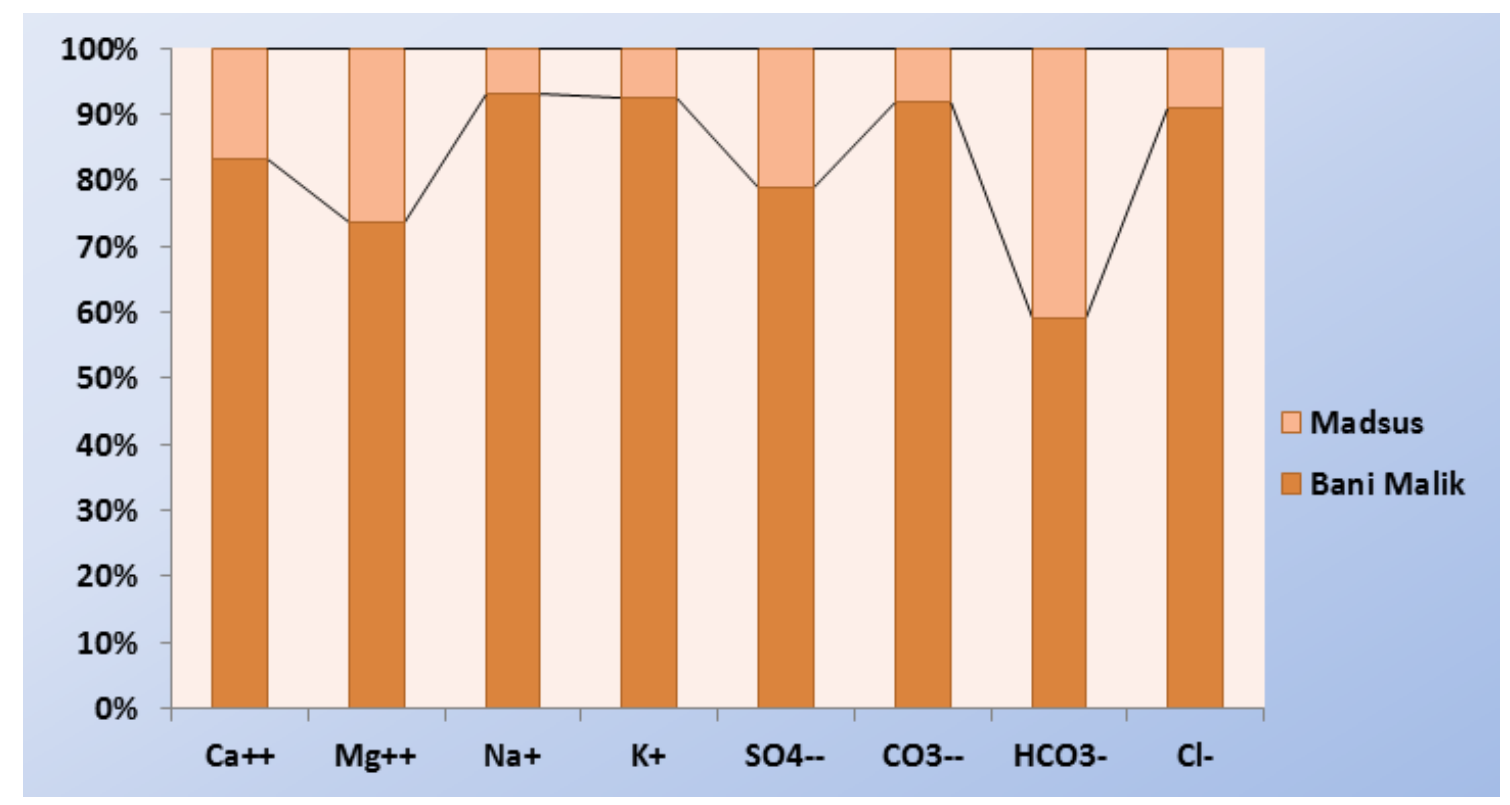

Figure 3. Comparison of major ions in Wadi Bani Malik and Wadi Madsus 
Figure 5 shows two intersecting lines connecting the data points of Wadi Bani Malik and Wadi Madsus. (e.g., well no 2 with 24 and well no 5, 10 with well no 20). The similarity of chemical composition of one wadi with the other is shown by these intersecting lines.

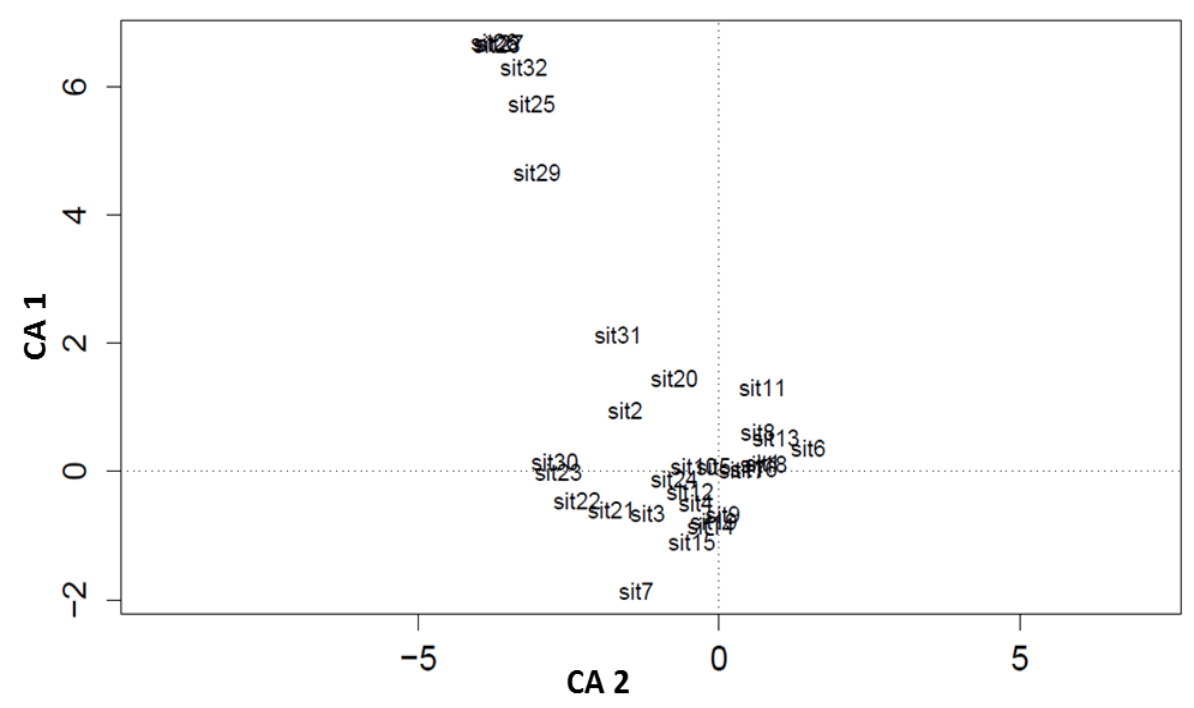

Figure 4. Correspondence Analysis plot of water samples in Wadi Bani Malik (sit 1-19) and Wadi Madsus (sit 20-32). (Sit represents: well no)

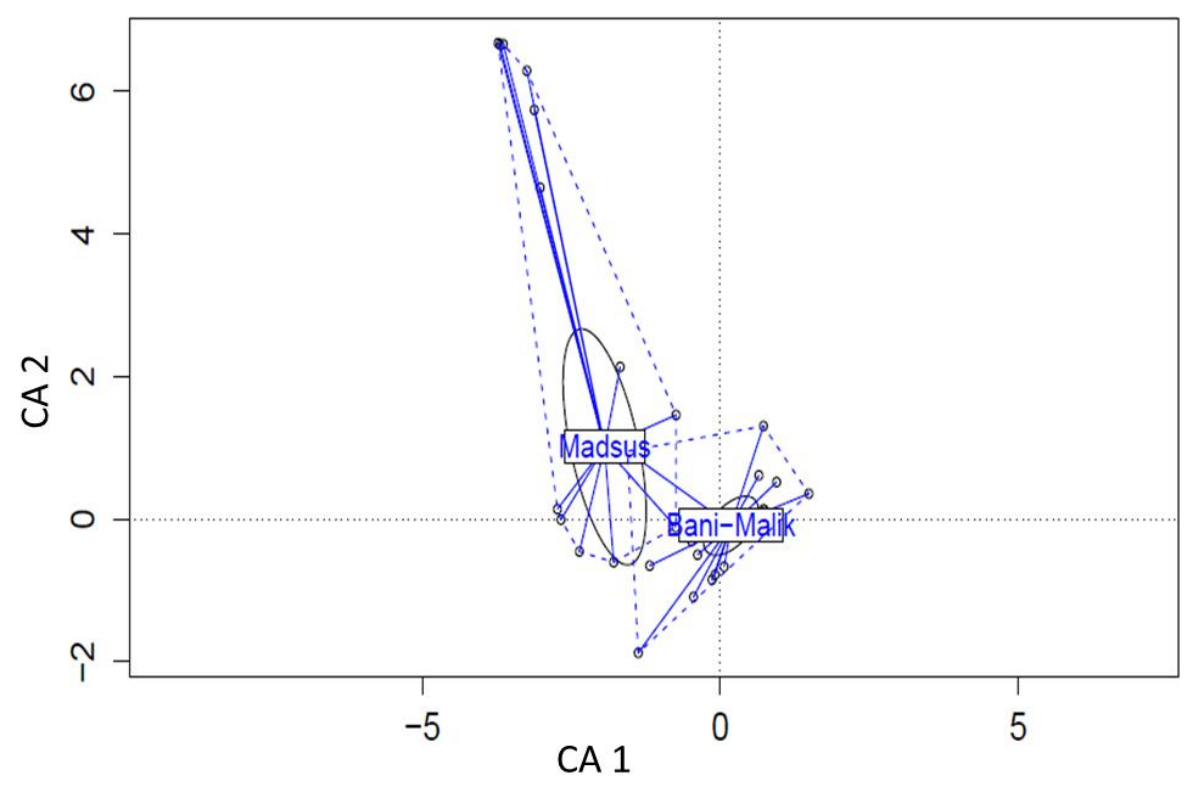

Figure 5. Correspondence Analysis plot of water samples in Wadi Bani Malik and Wadi Madsus

\subsection{ANOSIM (Analysis of Similarity)}

Analysis of similarity (ANOSIM) using $R$ package vegan indicates a strong correlation $(R=0.82)$ between Wadi Bani Malik and Wadi Madsus with a significance level of $P=0.001$ (figure 6). According to ANOSIM, the strength of the factor closer to 1 indicates a high separation between the two datasets. Therefore, the high value of $R$ found for the dataset provides an evidence that specifies the high dissimilarity in between the two wadis. In the case of Wadi Bani Malik scenario, the results show that in term of concentration of contamination, wells of Wadi Bani Malik area are significantly different from the wells of Wadi Madsus. And it is shown that sewage dumping significantly $(P=0.001)$ contaminated the groundwater quality in the Bani Malik area. 


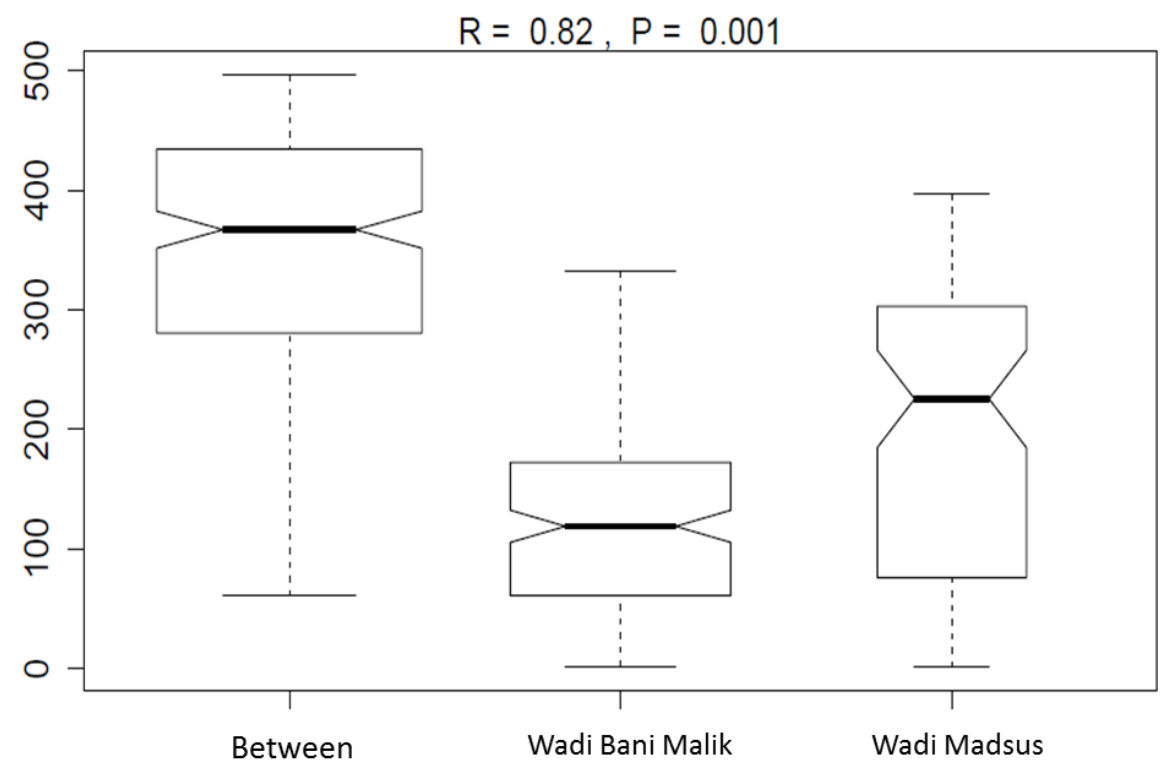

Figure 6. Analysis of Similarity between Wadi Bani Malik and Wadi Madsus

\section{Conclusions}

The results of groundwater chemical analysis performed on 19 samples obtained from Wadi Bani Malik showed much higher concentrations of major ions as compared to the drinking water standards. As the Wadi had a history of being a dumping site for untreated sewage, the data were compared with the hydrogeochemical data of an adjacent wadi not known to have the historic contamination (i.e., Wadi Madsus). Both the datasets were statistically analyzed to determine the similarities and to provide the statistical evidence of the contamination at Wadi Bani Malik. Principal Coordinate Analysis indicated that some of the wells in both of the wadis have same compositional trend and also some samples overlap within the same area. The data were compared by performing the Analysis of Similarity. Analysis of similarity (ANOSIM) using $R$ package vegan indicates a strong correlation $(R=0.82)$ between Wadi Bani Malik and Wadi Madsus. The $P$ factor calculated while performing the analysis suggests that sewage dumping significantly contaminated $(P=0.001)$ the groundwater quality of the Bani Malik area.

\section{Acknowledgment}

Dr Imran Khan of the Biochemistry Department, King Abdulaziz University Jeddah, has been acknowledged for his useful input in processing the data for Multivariate Statistical Analysis.

\section{References:}

Clarke K. and Warwick R. (2001), An approach to statistical analysis and interpretation: Change in Marine Communities, v. 2, Primer-E Ltd: Plymouth, UK

Dehghanzadeh R., Hir N.S., Sis J.S. and Taghipour H. (2014), Integrated assessment of spatial and temporal variations of groundwater quality in the eastern area of Urmia Salt Lake Basin using multivariate statistical analysis, Water Resources Management, 29(4), 1351-1364.

Dragon K. (2008), The influence of anthropogenic contamination on the groundwater chemistry of a semi-confined aquifer (the Wielkopolska Buried Valley Aquifer, Poland), Water resources management, 22(3), 343-355.

Elfeki A., Ewea H. and Al-Amri N. (2010), Linking Groundwater Flow and Transport Models, GIS Technology, Satellite Images and Uncertainty Quantification for Decision Making: Buraiman Lake Case Study Jeddah, Saudi Arabia, 4 International Conference on Water Resources and Arid Environments: Riyadh, Saudi Arabia, p. 122-130.

Ewea H. (2010), Hydrological Analysis Of Flooding Wastewater Lake In Jeddah: Saudi Arabia, J.K.A.U.: Met., Env and Arid Land Agric. Sci. 21(1), 125-142. 
Forrest M.J., Kulongoski J.T., Edwards M.S., Farrar C.D., Belitz K. and Norris R.D. (2013), Hydrothermal contamination of public supply wells in Napa and Sonoma Valleys, California, Applied Geochemistry, 33, 25-40.

Griebler C., Stein H., Kellermann C., Berkhoff S., Brielmann H., Schmidt S., Selesi D., Steube C., Fuchs A. and Hahn H.J. (2010), Ecological assessment of groundwater ecosystems-vision or illusion?, Ecological Engineering, 36(9), 1174-1190.

Hahn H.J. and Fuchs A. (2009), Distribution patterns of groundwater communities across aquifer types in southwestern Germany, Freshwater Biology, 54(4), 848-860.

Ibekwe A.M., Leddy M.B., Bold R.M. and Graves A.K. (2012), Bacterial community composition in low-flowing river water with different sources of pollutants, FEMS Microbiology Ecology, 79(1), 155-166.

Jabal M.S.A., Abustan I., Rozaimy M.R. and El Najar H. (2015), Groundwater beneath the urban area of Khan Younis City, southern Gaza Strip (Palestine): hydrochemistry and water quality, Arabian Journal of Geosciences, 8, 2203-2215.

Lin C.Y., Abdullah M.H., Praveena S.M., Yahaya A.H.B. and Musta B. (2012), Delineation of temporal variability and governing factors influencing the spatial variability of shallow groundwater chemistry in a tropical sedimentary island, Journal of Hydrology, 432, 26-42.

Moore T. and Al-Rehaili M. (1989), Geologic map of the Makkah Quadrangle: Sheet 21D, Kingdom of Saudi Arabia, Ministry of Petroleum and Mineral Resources, Deputy Ministry For Mineral Resources Publication, Jeddah, SA.

Morsi M., Farrag A., Elewa A. and El Sayed E. (2015), Quantitative Analyses of Surface Water and Groundwater Resources around the River Nile, Assiut Governorate, Upper Egypt: Water Quality in Relation to Anthropogenic Activities, Journal of Hydrogeology and Hydrologic Engineering, 4(3), doi:10.4172/2325-9647.1000124.

Ramette A. (2007), Multivariate analyses in microbial ecology, FEMS Microbiology Ecology, 62(2), 142-160.

Rehman F., Abuelnaga H.S.O., Harbi H.M., Tariq C. and Atef A.H. (2016a), Using a combined Electrical Resistivity Imaging and Induced Polarization Techniques with the chemical analysis in determining of groundwater pollution at Al Misk Lake, Eastern Jeddah, Saudi Arabia, Arabian Journal of Geosciences, 9:286, DOI $10.1007 / \mathrm{s} 12517-016-2423-9$

Rehman F. and Cheema T. (2016), Effects of sewage waste disposal on the groundwater quality and agricultural potential of a floodplain near Jeddah, Saudi Arabia, Arabian Journal of Geosciences, 9:307, doi:10.1007/s12517016-2340-y.

Rehman F., Helmy S.O.A., Hussein M.H. and Ali H.A. (2016b), Application of Vertical Electrical Sounding and Water Analysis for Study the Contaminated Area at Al Misk Lake, Eastern Jeddah, Saudi Arabia, Nature Environment and Pollution Technology, 15(1), 311-316.

Schmidt S.I., Hellweg J., Hahn H.J., Hatton T.J. and Humphreys W.F. (2007), Does groundwater influence the sediment fauna beneath a small, sandy stream?, Limnologica-Ecology and Management of Inland Waters, 37(2), 208225.

Sharaf M.A.M. (2012), Hydrochemistry of the groundwater aquifer in Wadi Madsus area, Makkah district, western Saudi Arabian Shield, Saudi Arabia, Egyptian Journal of Geology, 56, 19-31.

Srinivasamoorthy K., Gopinath M., Chidambaram S., Vasanthavigar M. and Sarma V. (2014), Hydrochemical characterization and quality appraisal of groundwater from Pungar sub basin, Tamilnadu, India, Journal of King Saud University-Science, 26(1), 37-52.

Subyani A.M. and Al Ahmadi M.E. (2010), Multivariate statistical analysis of groundwater quality in Wadi Ranyah, Saudi Arabia, JAKU: Earth Sciences, 21(2), 29-46.

Sun L. and Gui H. (2015), Statistical Analysis for Understanding Groundwater Chemical Variations, Nature Environment and Pollution Technology, 14(1), 41-46.

Suresh M., Gurugnanam B., Vasudevan S., Rajeshkanna B., Dharanirajan K., Prabhakaran N. and Nagar A. (2009), Hydrogeochemical Studies by Multivariate Statistical Analysis in Upper Thirumanimuthar Sub-basin, Cauvery River, Tamil Nadu, India, Nature Environment and Pollution Technology, 8(4), 693-700.

WHO (2011), Guidelines for drinking-water quality, World Health Organization.

Zhang L., Song X., Xia J., Yuan R., Zhang Y., Liu X. and Han D. (2011), Major element chemistry of the Huai River basin, China, Applied Geochemistry, 26(3), 293-300.

Zuur A., Leno E.N. and Smith G.M. (2007), Analysing ecological data, Springer Science \& Business Media. 